\title{
Article
}

\section{Improving Personnel Management by Organizational Projects: Implications for Open Innovation}

\author{
Alexander Bril ${ }^{1}$, Olga Kalinina ${ }^{1, *}$, Olga Valebnikova ${ }^{1}$, , Natalia Valebnikova ${ }^{1}$, Marisa Camastral ${ }^{2}$, \\ Dmitry Shustov ${ }^{3}$ and Natalya Ostrovskaya ${ }^{3}$ \\ 1 Graduate School of Service and Trade, Peter the Great St. Petersburg Polytechnic University, \\ 195251 St. Petersburg, Russia; bar.bril@yandex.ru (A.B.); olgavalebnikova@gmail.com (O.V.); \\ na0903@gmail.com (N.V.) \\ 2 Gazprom Marketing and Trading Ltd., London NW1 3BF, UK; Marisa.Camastral@gazprom-mt.com \\ 3 Financial University under the Government of the Russian Federation, St. Petersburg Branch, \\ 125993 Moscow, Russia; dim_shu@mail.ru (D.S.); nvostrovskaya@fa.ru (N.O.) \\ * Correspondence: olgakalinina@bk.ru or ovkalinina@spbstu.ru
}

Citation: Bril, A.; Kalinina, O.; Valebnikova, O.; Valebnikova, N.; Camastral, M.; Shustov, D.; Ostrovskaya, N. Improving Personnel Management by Organizational Projects: Implications for Open Innovation. J. Open Innov. Technol. Mark. Complex. 2021, 7, 105. https:// doi.org/10.3390/joitmc7020105

Received: 3 March 2021

Accepted: 22 March 2021

Published: 24 March 2021

Publisher's Note: MDPI stays neutral with regard to jurisdictional claims in published maps and institutional affiliations.

Copyright: (c) 2021 by the authors. Licensee MDPI, Basel, Switzerland. This article is an open access article distributed under the terms and conditions of the Creative Commons Attribution (CC BY) license (https:/ / creativecommons.org/licenses/by/ $4.0 /)$.

\begin{abstract}
The methodology and basic elements of the business process of one-stage economic assessment of organizational projects for personnel management at Russian enterprises are presented. The aim of the study is to analyze and develop clear criteria for assessing the effectiveness of projects and improving personnel management systems for enterprises of different industries and types of activities. The economic and financial assessment of projects aimed the development of personnel management systems is based on the general methodology for the commercial assessment of projects, which is presented in the so-called United Nations Industrial Development Organization (UNIDO) methodology. The article proposes the resulting model "maximum costs of the HRM". The features of the proposed methodology are based on the assumption of future digitalization and are associated with the need for a preliminary calculation of the maximum possible project costs, localization of the projects under consideration at existing enterprises, and the mandatory separation of project goals for increasing sales or reducing the number of personnel. In accordance with the different objectives of the projects, a certain order and special indicators of decision-making are proposed. Companies with a different structure of costs could be assessed via the proposed model and the results presented in the article. The model allows us to create an information base for reasonable decision-making on HR management (HRM) projects and future digitalization of settlements.
\end{abstract}

Keywords: organizational project; HR management; economic assessment; economies of scale; personnel management; labor productivity; profitability; standard costs

\section{Introduction}

Digital transformation of business processes is the most important area of the modern Russian economy [1,2]. Several factors favoring the transition to a digital economy have already evolved: the Internet is actively used by the population, there is high demand for digital content and services, and there is robust participation on social media. On the other hand, Russia continues to lag behind the EU countries in terms of digitalization of business, digital skills, and e-government services. Furthermore, businesses often lack the motivation for digital transformation due to restrictive administrative barriers and inconsistent legal frameworks [3]. Therefore, developing a comprehensive strategy for the digital economy, providing steady economic growth, and providing social prosperity are among the country's top priorities. Aside from removing the barriers to create a more liberal climate in the labor market and working to provide an effective communication infrastructure, the strategy should necessarily focus on developing human capital, as employees with unique skills and knowledge are becoming one of the key resources of the digital economy. In this context, it seems particularly important to carefully explore the 
effects induced by digital technologies in personnel management. The technologies can be used for solving various management problems, analyzing links between industrial and commercial facilities, and developing decision-making criteria and a regulatory framework for calculating costs and revenues [4,5]. An organization's personnel management system is a part of the general management system; achieving the main goals of the organization in the market depends on whether this system has been constructed properly and functions effectively.

Personnel management in the digital age is a focus of considerable attention; a large amount of scientific and practical literature is dedicated to diverse aspects of this problem [6-9]. Investment and organizational projects are used by enterprises to improve personnel management systems [10]. The main difficulty in making decisions on the financing of work is the difficulty of reliably determining their economic and financial effect. The United Nations Industrial Development Organization (UNIDO) methodology can be used for commercial evaluation of projects [11]. The traditional school of personnel management considers projects related to personnel from the perspective of the personnel management process without taking capital investments into account [12]. The project approach, on the other hand, has few methods that do not rely on investment analysis. Personnel management projects often have a greater social effect and only indirectly affect the growth of sales and profits [13]. A significant part of these projects requires relatively small costs in comparison with the renovation of technology and equipment, and the "human factor" has a greater influence in decision-making than analytical calculations.

In the context of digitalization, the key skills for people are adapting to a changing environment and being able to constantly acquire and apply new knowledge [14]. A growing concern is that in the future, with the advent of robots and increasing automation, there will be a threat of severe unemployment, which is why people need to constantly gain new skills, instead of focusing on a specific area $[15,16]$. Of course, the structure of employment will change, but this does not mean that people will not be able to find work: on the contrary, professions will appear that do not currently exist. In the context of digitalization, information analysis will remain an advantage of the employee's work [17]. New technologies will be able to help facilitate more convenient and faster analysis, but decision-making remains with the individual. In this regard, an important issue yet to be properly addressed in literature is improving the methodology for calculating project costs depending on the objectives set in the analysis.

The goal of the study is to analyze and develop clear criteria for assessing the effectiveness of projects, to describe the regulatory framework for costs and incomes from improving personnel management systems for enterprises of different industries, sizes and profiles. In addition, the authors aim to identify the key points and the most difficult situations arising in economic calculations and in making decisions on financing and implementing projects.

In view of the goals set, the authors make an attempt to compile a comprehensive methodology for determining the overall maximum cost of financing HRM projects of specific enterprises, choosing an efficiency criterion and constructing a procedure for determining the economic efficiency of organizational projects.

\section{Theoretical Fundamentals and Methodology}

\subsection{Literature Review}

The study of the issues of economic analysis of investments in HR as the most important resource of an organization has always been relevant in the Russian Federation and other countries of the world. Russian and other researchers consider "human resources" to be a set of people in an organization who have certain knowledge, skills, qualities, and potential $[18,19]$. The modern rethinking of approaches to people management is taking place against the background of the creation of effective concepts of human resource management and in conditions of limited funding [20]. Intellectual and creative activity is currently regarded by many scholars as the main source of innovation [21]. Fundamental 
issues related to different aspects of establishing effective HRM practices for an enterprise have been considered, for example, by Lado and Wilson [22], Kucharčíková et al. [23], and Albrecht et al. [24], Viktorova et al. [25], and Valebnikova et al. [26].

Investment activity is a particularly intriguing subject in relation to human resources of the organization; it has been considered by numerous Russian and foreign researchers, such as Shaw et al. [27], Lopez-Cabrales, and Valle-Cabrera [28], Wang et al. [29], and Lo et al. [30]. Diverse elements of the HRM system as an innovative component of the enterprise were assessed by Laursen et al. [31], Kim and Choi [13], and Wikhamn [32]. The issues of measuring and diagnosing the personnel potential of an enterprise and improving the current personnel costs were discussed by Sardi et al. [33], Nijs et al. [34], and Osranek and Zink [35].

Despite the large number of works dedicated to economic and financial analysis of projects for personnel management, many practical issues have not been fully resolved [36,37]. In particular, numerous attempts have been made to construct innovative methodologies for modern HRM practices [38,39]. Intriguing examples are presented in $[40,41]$, dealing with employer branding, i.e., a range of measures for managing and influencing an enterprise's reputation as an employer among current or potential employees and key stakeholders. A positive relationship was found between not only employer branding and improving an enterprise's reputation, but also, perhaps even more significantly, increasing the confidence and motivation of individual employees, contributing to their better overall performance. In the digital environment, where skilled and experienced workers are one of the rare resources available, such methodologies play a crucial role in forming a responsible organizational culture.

Widespread and rather complex issues of HR management at operating enterprises include the procedures for developing personnel management projects, their economic and social assessment, choosing those that are acceptable and effective for each company, and their practical implementation. The small amount of costs and the difficulty of reliably determining the future effect of HRM projects stimulate managers to make intuitive decisions with the full influence of the "human factor". While team members should only know their responsibilities, the project manager should create project plans based on common goals $[42,43]$. The processes of digitalization of economic and financial activities require standardization of business processes, the development of clear decision-making criteria, and the development of a regulatory framework for calculations. Most organizations design their HR processes to encourage certain desirable staff behaviors (norms), which is believed to maximize the chance of organizational success. This set of processes is called strategic human resource management (SHRM) [44].

Human resource management drastically affects the total cost of the project because it controls the productivity of materials and equipment that constitutes the remainder of the direct costs $[45,46]$.

The project-based company is generally defined as one in which the majority of products made or services offered are not bespoke designs for customers [47]. Gareis [48] takes a more proactive view where the project-oriented organization makes a conscious choice to be so.

Based on the authors' research in the field of economic analysis of the implementation of work on HRM at operating enterprises, it was found that for operational projects, the calculation scheme can be significantly simplified and limited only to the second stage. As part of HRM integration, employees will be able to estimate their labor costs for performing various tasks using the method under consideration, managers will be able to assess the capabilities of subordinates and select the necessary leadership style in the best way [49].

Organizational projects differ in financing from a company's turnover and attributing the costs of their implementation to a fixed part of the operating costs. The terms of implementation of organizational projects usually do not exceed a year. For such projects, the calculation of discounted indicators of commercial efficiency is not required, and the calculation of payback periods is necessary in individual special cases [50,51]. The 
effectiveness of such projects is determined by their impact on the financial condition of the enterprise and the growth of its profitability. In accordance with the authors' approach on the basis of UNIDO methodology, the most acceptable criterion for making decisions on the assessment of HRM projects is a possible increase in cashflow raised from labor productivity. The use of this very criterion made it possible to develop a fairly simple methodology for assessing the economic efficiency of organizational HRM projects at operating enterprises.

Considering the business processes of various HRM projects, it was also found that the most difficult task was to determine the results, i.e., the planned income, for the projects aimed at increasing product sales and improving labor productivity [52]. This is due to the existing regulatory framework established for planning. Projects aimed at improving the production culture and qualifications of the production personnel, motivation and incentives, adaptation and mentoring, HR marketing, HR planning, reducing staff turnover, increasing team spirit in the company, etc., typically yield an increase in labor productivity of $0.3-1.1 \%$ or more within this framework $[53,54]$. The figure varies greatly for businesses of different sizes. The effect of "economies of scale" is that the same organizational project can bring an increase in revenue and profit of 10 million RUB per year at a large enterprise, and 50,000 RUB per year or less at a small enterprise. As a result, implementing HRM projects worth up to 10 million RUB is effective for a large enterprise, while the upper cost limit is 20-30 times less for a small one. Therefore, the primary task was to analyze the costs of such projects and possible methods for increasing profits.

\subsection{Methodology for Developing the Model}

The considered model of preliminary cost estimation should be rather simple and acceptable for practical application. The main purpose of the model development is to allow making more reasonable decisions on organizational HRM projects, which are currently being made based on the experience and intuition of managers. The model has been tested, but it remains controversial from the point of view of its complication by introducing additional variables, such as cost rates for standard HRM projects, planned profitability of sales, and other factors. In the process of researching the economic issues of HRM practices at enterprises, the authors worked out the technologies and business processes for the development and implementation of HRM projects in detail. Based on this, the key points and the most difficult situations in economic calculations and in making decisions on financing and implementing projects were identified. So, it was found that investments in improving the HRM systems of enterprises pursue the same goals as investments in fixed assets of companies, as well as in the opening of new enterprises and industries. Three main goals of HR projects in operating enterprises were identified:

- growth in sales volumes and labor productivity,

- reduction of operating costs and headcount,

- growth in sales and a reduction in operating costs.

In this regard, the authors assumed that the economic and financial assessment of projects aimed at the development of personnel management systems can be based on the general methodology for the commercial assessment of projects, which is presented in the so-called UNIDO methodology [55], and is the basis for numerous banking and other methods of assessing the effectiveness of projects operating in the Russian Federation and other countries.

At the same time, it was found that a significantly larger share among HRM projects (in comparison with innovative and technological projects aimed at improving fixed assets and equipment), i.e., up to $90 \%$, is taken by relatively inexpensive and short-term organizational projects [56] (see Table 1). 
Table 1. Main types and focus of HR projects.

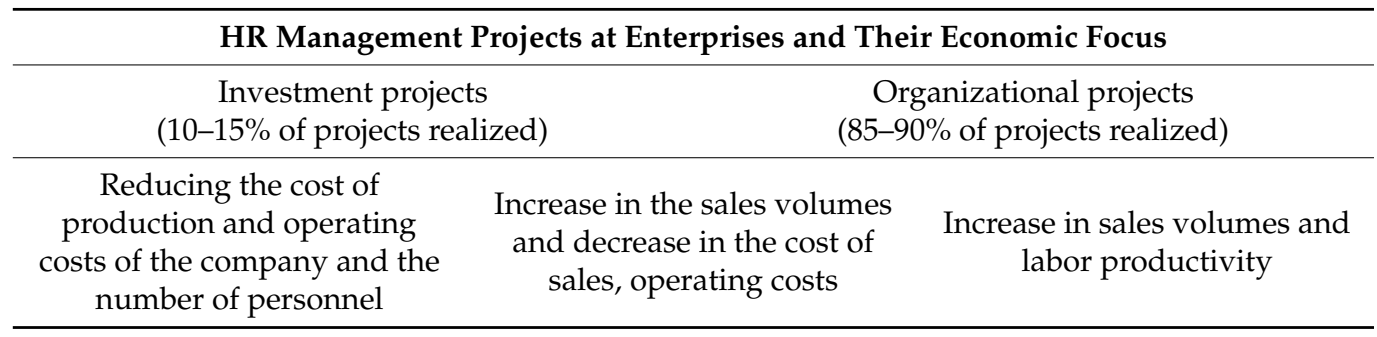

The authors' earlier studies $[57,58]$ considered two- and one-stage systems for economic evaluation of projects for personnel management. Commercial efficiency in such systems is assessed based on return on investment (ROI) calculations and discount indicators. Additionally, studies were carried out on the impact of project implementation on labor productivity, profit growth, profitability of sales and assets, and changes in the level of operational risks for a given company. A specific set of indicators was constructed for decision-making at each stage. Additional indicators were chosen based on the methodology for financial diagnostics of enterprises, focusing on a specific company, regarded as an object, where the project under consideration is implemented.

The methodology for localizing projects for HRM at enterprises was considered in [59]. Issues of risk assessment based on the mechanism of operational leverage in the implementation of HRM projects were also considered in [60].

Currently, there are multiple problems at enterprises concerning personnel management. In particular, the system of motivation and rewards is poorly formalized and does not include the characteristics related to human capital. Knowledge management is not carried out systematically. Organizational policies do not reconcile corporate and individual values. No risk-based approach is applied in planning and developing HR processes. Talent and leadership management is not centralized; in fact, improving leadership skills and engaging employees in innovative development are not encouraged sufficiently. Functions performed by employees are often duplicated. Introducing HRM can help resolve these problems.

\section{Results}

3.1. Testing and Validating the Methodology for Assessment of Personnel Management Processes

Analysis of business processes aimed at improving HRM at enterprises uncovered the following variable factors affecting the maximum possible amount of costs for the project depending on the criterion of profit growth from sales:

- the annual volume of sales of the operating enterprise, Sales (mln RUB per year),

- the share of variable costs in the volume of sales, $S_{v}$,

- the planned percentage of increase in labor productivity and sales volumes as a result of the implementation of the HRM, $K_{p l}$,

- the actual and planned profitability of sales of the considered enterprise's return on sales (ROS) in \%.

The following dependence of the maximum acceptable amount of investment in the organizational HRM project-Dep $\max$-on the identified variables was established:

$$
\text { Dep } \max =\text { Sales } \times\left(K_{p l}-1.0\right) \times\left(1.0-S_{v}-\frac{R O S}{100}\right) .
$$

It was assumed that the maximum acceptable amount of investment in the HRM project $D e p_{\max }$ is limited by the additional profit from the company's sales, which appears as a result of an increase in labor productivity and an increase in the volume of product sales. In other words, if the costs of the HRM project are not more than the expected additional profit from sales, then the implementation of the project will not bring an economic loss (i.e., a decrease in the profit from sales received by the company before 
the project is implemented). However, such a project can bring significant social impact. An important point: to calculate Dep $\max$, not all additional profit from sales is calculated, but only part of it associated with savings in fixed costs (hereinafter additional profit from sales).

An objective analysis of business processes at operating enterprises in Russia in all spheres of activity shows that companies are constantly implementing many projects, both in personnel management and in other types of activities (software, logistics, production and sales technologies, etc.). Therefore, the authors considered it insufficiently justified to include all the planned profit from sales in the financing plan for HRM projects.

The following rationale can be proposed for this formula.

Firstly, the sum of fixed costs in the planned option and profit from sales due to savings in fixed costs could be considered as the planned volume of sales minus planned variable costs and minus planned profit from sales, which depends only on profitability:

$$
\text { sales } \times K_{p l}-\text { sales } \times K_{p l} \times S v-\text { sales } \times K_{p l} \times R O S / 100
$$

Secondly, fixed costs in the basic option do not change with increasing sales. Therefore, the fixed costs in the basic option are equal to the fixed costs in the planned option. So, the expression could be written:

$$
\text { sales }- \text { sales } \times S_{v}-\text { sales } \times \text { ROS } / 100
$$

Let us consider the difference between the first and the second expressions:

$\left(\right.$ sales $\times K_{p l}-$ sales $\times K_{p l} \times S_{v}-$ sales $\left.\times K_{p l} \times R O S / 100\right)-\left(\right.$ sales - sales $\times S_{v}-$ sales $\left.\times R O S / 100\right)$

This formula can be transformed as follows:

$$
\begin{aligned}
\text { Sales } \times K_{p l} \times & \left(1-S_{v}-R O S / 100\right)-\text { sales } \times\left(1-S_{v}-R O S / 100\right)= \\
& =\text { sales } \times\left(K_{p l}-1\right) \times\left(1-S_{v}-\text { ROS } / 100\right)
\end{aligned}
$$

Thus, formula (1) is obtained.

$K_{p l}$ is a coefficient that takes into account the planned growth in sales volumes of the enterprise as a result of the implementation of the HRM project. For example, an increase in sales of products by $1 \%$ is reflected by a coefficient of 1.01 , while an increase in sales by $0.5 \%$ is reflected by a coefficient of 1.005 , etc.

In Table 2, $K_{p l}$ equals $1 \%$. The data in Table 2 illustrate that at large enterprises, companies with a lower share of variable costs, and enterprises with a lower profitability when planning HRM projects, there are more financial opportunities for the implementation of these projects, i.e., the $D e p_{\max }$ value with the same planned growth in sales increases significantly by $1 \%$ as sales volumes increase from RUB 75 million to RUB 3500 million per year, the share of variable costs in revenue decreases from 0.90 to 0.60 and 0.30 , and profitability decreases from $7 \%$ to $4 \%$.

The resulting model "maximum costs for HRM ("MAXHRM") allows us to simply automate the first step of the business process of work to improve HR management at any enterprise. This step consists in determining what the maximum amount can be allocated from the company's turnover for HRM projects, without reducing sales profit and profitability. Table 2 shows the results of calculations for this model for enterprises, given in a comparable form in terms of sales and labor productivity.

The study of human capital management processes was carried out at small and medium-sized enterprises of various fields of activity, carrying out innovations in core activities and personnel management. The studied enterprises are engaged in the processing of agricultural products, the repairing of power equipment, as well as retail and wholesale trade. 
Table 2. Calculation of the maximum standard costs for the implementation of the organizational HR management (HRM) project with a planned increase in labor productivity and sales of products $K_{p l}$ by $1 \%$.

\begin{tabular}{ccccc}
\hline Enterprise & $\begin{array}{c}\text { Sales Volume for } \\
\text { Previous Year, Million } \\
\text { RUB/Year }\end{array}$ & $\begin{array}{c}\text { Share of Variable } \\
\text { Costs in Volume } \\
\text { of Sales }\end{array}$ & $\begin{array}{c}\text { Profitability of Sales for } \\
\text { Previous Year, \% ROS }\end{array}$ & $\begin{array}{c}\text { Maximum Acceptable } \\
\text { Amount of Investments in } \\
\text { HRM Project, Million RUB }\end{array}$ \\
\hline A 001 & 3500.0 & 0.90 & 7.0 & 1.050 \\
\hline A 001 & 3500.0 & 0.60 & 7.0 & 11.550 \\
\hline A 001 & 3500.0 & 0.30 & 7.0 & 22.050 \\
\hline A 001 & 3500.0 & 0.90 & 4.0 & 2.100 \\
\hline A 001 & 3500.0 & 0.60 & 4.0 & 12.600 \\
\hline B 003 & 75.0 & 0.90 & 7.0 & 0.023 \\
\hline B 003 & 75.0 & 0.60 & 7.0 & 0.247 \\
\hline B 003 & 75.0 & 0.30 & 7.0 & 0.450 \\
\hline B 003 & 75.0 & 0.90 & 4.0 & 0.045 \\
\hline B 003 & 75.0 & 0.60 & 4.0 & 0.270 \\
\hline
\end{tabular}

The presented material shows a significant difference in the maximum possible costs and, accordingly, the economic efficiency of the project, for example, to increase the production culture for a large and small enterprise. For a large trading company with an annual sales volume of 3.5 billion RUB and a share of variable costs in revenue of $90 \%$, this amount when planning a growth in sales volumes from the project by $1 \%$ is 1.050 million RUB. For a small enterprise with an annual turnover of 75 million RUB and with the same share of variable costs, this amount should not exceed 23,000 RUB.

In the process of studying the implementation of HRM projects at various enterprises, it was found that companies with a lower share of variable costs (i.e., working with a higher operational risk), as well as with a lower profitability of ROS, are more promising objects for the implementation of effective HRM projects. This is illustrated by the results of calculations using the "MAXHRM" model in Table 2. For enterprise A 001, with a share of variable costs in the volume of sales of $60 \%$, the maximum acceptable amount of investment in HRM projects increases to 11.55 million RUB, compared to 1.05 million RUB in the case of a share of variable costs of $90 \%$.

This is due to the fact that when implementing HRM projects aimed at increasing sales volumes, the cost of production increases less than the revenue, due to the presence of a constant part in them. A "scale effect" is formed, i.e., the relative savings in the company's fixed costs.

Thus, when planning an increase in sales as a result of the implementation of the UP project by $1 \%$, current costs (cost of goods sold) will increase with a share of variable costs in revenue of 0.9 by $0.9 \%$, and with a share of variable costs of 0.6 , will only increase by $0.6 \%$.

$$
0.9 \%-0.6 \%=0.3 \% ; 0.3 \% \text { of } 3500 \text { million RUB is } 10.50 \text { million RUB }
$$

For the second situation (for an enterprise with a greater share of fixed costs) an additional increase in sales profit for an enterprise with an annual sales volume of 3500 million RUB per year will be 10.50 million RUB. Accordingly, the maximum acceptable amount of investments in organizational HRM projects will also increase:

$$
1.05+10.50=11.55 \text { million RUB }
$$

In addition to the share of variable costs in revenue, an important factor determining the maximum amount of investments in organizational HRM projects at operating enterprises is the actually achieved level of profitability of ROS. The less profitable the 
enterprise is, the more it needs HRM projects and can allocate a larger amount for these organizational works. So, according to the data in Table 1, it can be seen that if the initial (starting) profitability of sales ROS for the enterprise under consideration is not $7 \%$, but $4 \%$, then the maximum acceptable amount of investment in HRM projects increases from 11.55 million RUB up to 12.6 million RUB.

Table 2 considers enterprises with approximately the same sales volumes and labor productivity from the sample under consideration, differing in the share of variable costs in sales (from 0.3 to 0.9 ) and profitability of sales (from $4 \%$ to $7 \%$ ). Enterprises with a lower share of variable costs and lower profitability have a higher level of operational (production) risks due to large investments in innovative activities.

The main goal of such activities is to increase production efficiency and to create competitive products, services, and activities that will bring additional profit in the foreseeable future. To effectively implement such models in enterprises, all business processes must be integrated and coordinated, and management and staff must have the determination and ability to implement them.

Based on the provisions of the previously developed two-stage methodology for the commercial assessment of projects, the authors formulated and tested a one-stage methodology for the economic analysis of operational projects for personnel management. At the same time, the procedure and criteria for assessing the impact of project implementation on labor productivity and profit growth of the company in question, profitability of sales and assets, the level of production, and operational risks were developed.

The proposed methodology for calculating the cost based on the economic potential of the business of operational personnel management projects includes three main areas:

- $\quad$ fixing a plan to identify the superiority and defects of events, centers of decreases and increases in costs, and directions of raising and lowering risks,

- $\quad$ finding and evaluating the criteria and characteristics of costs as well as the performance of such solutions for the organization

- drawing up a risk map and assessing changes in risks under the influence of various measures to minimize them.

From the point of view of financial assessment in the proposed methodology, plans are divided into 3 groups by target orientation:

- $\quad$ plans, which the implementation of the increase in the volume of sales of products depends on;

- plans, investments in which only affect the reduction of labor costs, the number of personnel and, in accordance with this, current costs and production costs;

- $\quad$ the components of the personnel management system, which affect both the reduction of operating costs, for example, and the increase in the volume of sales of products.

Efforts to motivate and incentivize sales personnel or open irrespective training centers to increase sales and profits are good examples of the above. On the other hand, the automation of work in production units and the training of personnel to perform new functions mainly affect the reduction of headcount, growth of labor productivity, and a decrease in the operating costs of the enterprise.

The main criterion of efficiency for organizational HRM projects, which differ in terms of goals and technologies, was adopted as a single one: a constant increase in profit from sales or increasing profitability of ROS. This gain or additional profit from sales depends on the relative reduction in cost of sales and operating costs for the project. Therefore, the basis for calculating the effectiveness of organizational HRM projects according to the proposed methodology is the calculation of project costs and analysis of changes in current costs of the enterprise in question. It is for the analysis of current costs that the controlled characteristics of the enterprise are recommended.

Additional income is always associated with increased financial, commercial and industrial risks. In this regard, the authors' methodology introduced controllable charac- 
teristics of the company in terms of risk change of operational leverage and the financial safety margin.

\subsection{Results Obtained Using the Proposed Methodology}

Numerous calculations were carried out for operating small and medium-sized businesses, the results of which are partially presented in Tables 3 and 4 .

Table 3. The results of the economic assessment of PM (personnel management) projects for a small enterprise.

\begin{tabular}{|c|c|c|c|c|}
\hline Economic Indicators & Basic (Original) Option & Option 1 & Option 2 & Option 3 \\
\hline Number of staff & 21 & 21 & 21 & 21 \\
\hline Annual sales volume, RUB mln & 152.0 & 153.368 & 152.608 & 152.00 \\
\hline Sales volume growth in $\%$ & - & 0.9 & 0.4 & - \\
\hline Cost of production (operating costs), RUB mln, including & 148.0 & 149.883 & 148.748 & 147.848 \\
\hline Fixed costs & 137.0 & 138.233 & 137.548 & 137.00 \\
\hline Variable costs & 11.0 & 11.650 & 11.200 & 10.848 \\
\hline Increase in fixed costs & & 0.650 & 0.200 & 0.150 \\
\hline Decrease in fixed costs & & - & - & 0.302 \\
\hline Profit from sales, RUB mln & 4.0 & 3.485 & 3.860 & 4.152 \\
\hline Increase in profit from sales & & -0.515 & -0.140 & 0.152 \\
\hline Labor productivity, million RUB/person per month & 0.603 & 0.609 & 0.606 & 0.603 \\
\hline Return on sales, ROS, $\%$ & 2.63 & 2.27 & 2.53 & 2.73 \\
\hline Break-even threshold, Million RUB & 111.47 & 118.05 & 113.49 & 109.92 \\
\hline Financial safety margin & 40.53 & 35.31 & 39.11 & 42.08 \\
\hline Operating leverage & 3.75 & 4.34 & 3.90 & 3.61 \\
\hline
\end{tabular}

Table 4. The results of the economic assessment of HRM projects for a small innovative enterprise.

\begin{tabular}{|c|c|c|c|}
\hline Economic Indicators & Basic Option & Option 1 & Option 2 \\
\hline Purpose of project: reducing cost due to staff reduction & & Divisions of management & Divisions of production \\
\hline Number of personnel & 55 & 48 & 35 \\
\hline Project costs, Million RUB & - & 0.01 & 0.01 \\
\hline Annual sales, Million RUB/year & 190,000 & 190,000 & 190,000 \\
\hline Cost (operating costs) Million RUB/year, including & 160.000 & 158.8 & 158.0 \\
\hline Variable costs & 120.0 & 120.0 & 112.0 \\
\hline Fixed costs & 40.0 & 38.8 & 46.0 \\
\hline Profit from sales, Million RUB/year & 30.0 & 31.2 & 32.0 \\
\hline $\begin{array}{l}\text { Increase (additional profit) of profit from sales, Million } \\
\text { RUB/year }\end{array}$ & - & 1.2 & 2.0 \\
\hline Payback period, year & - & Less than half year & Less than half year \\
\hline $\begin{array}{c}\text { Labor productivity, (sales per person/month) } \\
\text { thousand RUB }\end{array}$ & 287.9 & 329.9 & 452.4 \\
\hline Return on sales, $\%$ & 15.8 & 16.4 & 16.8 \\
\hline Operating leverage & 2.33 & 2.24 & 2.44 \\
\hline
\end{tabular}

HRM projects aimed at increasing the sales of products in companies with a high level of variable costs and relatively low fixed costs are less likely to affect additional profits and labor productivity growth due to "economies of scale". This is illustrated by the calculation model (Tables 2-4).

According to the cost structure of the actively innovative companies (the share of variable and fixed costs shown in Table 1 and labor productivity in Tables 3 and 4), the authors could make an important conclusion. Tables $2-4$ contain the results raising from the comparison of the cost structure of the enterprises actively investing in innovations. 
The use of the proposed methodology for the economic assessment of organizational HRM projects makes it possible to create a sufficiently substantiated information base for making effective decisions, improving and automating calculations in the context of the future digitalization of the Russian economy. The research shows the difference in the economic indicators between the 4 options. Innovative companies with high fixed costs could be more effective at increasing the volume of their activities but becoming large-scale businesses. Projects aimed at increasing labor productivity and, accordingly, increasing sales of products by $0.9 \%$ for option 1 and by $0.4 \%$ for option 2 are ineffective by calculation. Option 3 of the project was aimed at purchasing special software for organizing the remote work of employees and reducing the company's leased space by $40 \%$ for a total amount of 0.302 million RUB per year. The cost structure investigation could help with assessing projects clearly from the investments' point of view. In the first two options, the HRM projects aimed at reducing the number of employees may be more cost-effective. The results of one of these calculations for a small innovative enterprise are presented below. The case of Russia shows that the investor judging the effectiveness of HRM projects should take into account the cost structures of innovative enterprises which could be ineffective for small innovative enterprises (effective Russian innovative companies as a rule differ from its large-scale businesses).

According to the authors' methodology, special comparative tables are recommended. Table 3 shows the results of the economic analysis of three HRM projects, two of which are aimed at increasing labor productivity, and the third at reducing the current costs of the enterprise and reducing the cost.

The profit from sales will decrease for the enterprise by 0.515 million RUB as a result of option 1, and by 0.140 million RUB under option 2. As a result of their implementation, project costs (in Table 2, the increase in fixed costs of the enterprise) of 0.650 and 0.200 million RUB, respectively, are not covered by additional sales profit. Other controllable economic characteristics, besides labor productivity, also decrease. Thus, the profitability of ROS should decrease from $2.63 \%$ to $2.27 \%$ and $2.53 \%$, respectively, under options 1 and 2. The operational risks of the enterprise's activities increase, the margin of financial strength decreases, and the operating leverage increases.

Using the model according to options 1 and 2, can immediately give the maximum allowable amounts for effective projects (i.e., additional profit from sales excluding the project cost) for option 1 as 99,000 RUB and for option 2 as 44,000 RUB, which involves much smaller planned costs for these projects. When drawing up a special calculation program, after receiving too small maximum allowable amounts, further calculations can be omitted. With the digitalization of settlements, this issue will be resolved automatically.

In option 3, in contrast to the first two, the result of the sale is determined quite clearly and is expressed in a specific amount of reduction in rental payments during the year. For a small enterprise, such a project turns out to be more effective than projects aimed at increasing labor productivity and sales. If we return to Table 1 , it is clear that for a larger enterprise, options 1 and 2 could be more effective.

Table 4 shows the results of an economic analysis of two HRM projects aimed only at reducing the number of personnel in a small innovative manufacturing enterprise.

For this enterprise, when working out the development plan, the options for HRM were also considered, aimed at increasing the volume of sales of products. As can be seen from the table, this company has a relatively high share of variable costs in the volume of sales of $63.3 \%$ (120 of 190 million RUB). As a result, the option of the personnel motivation project aimed at increasing the volume of product sales by $0.6 \%$ allows for planning the maximum amount of project costs (i.e., additional profit from sales excluding project costs) with an amount of 0.240 million RUB. In accordance with the model:

$$
D e p_{\max }=190 \times(1.006-1.0) \times(1.0-0.632-0.158)=0.240
$$

This is significantly less than the development options presented in Table 3, aimed at reducing the number of personnel and providing additional profit from sales of 1.2 and 2.0 mil- 
lion RUB. The information received is enough to make an acceptable effective decision at the level of enterprise development planning.

Such an assessment allows making more informed decisions on the implementation of operational HRM projects. Table 3 shows the reporting data of the operating enterprise (baseline-basic option) and the results of economic analysis of three HRM projects, two of which are aimed at increasing labor productivity by $0.9 \%$ and $0.4 \%$, and the third is aimed at reducing the current costs of the enterprise and reducing the cost.

The results of calculations using the authors' methodology show that projects aimed at increasing labor productivity and, accordingly, an increase in sales of products by $0.9 \%$ for option 1 and by $0.4 \%$ for option 2 are ineffective. The profit from sales will decrease for the enterprise as a result of the sale of option 1 by 0.515 million rubles, and under option 2 by 0.140 million rubles. As a result of their implementation, project costs (in Table 4, the increase in fixed costs of the enterprise) 0.650 and 0.200 million rubles are not covered by additional sales profit. As a result of the implementation of these projects, the company may suffer losses.

Such information is useful for a manager who makes decisions on the implementation of a project. If he considers that these projects to be important for solving social problems, then he can estimate in terms of what it will cost the enterprise to obtain the desired social effect.

The rest of the indicators in the table: labor productivity, profitability of sales ROS, break-even threshold, financial strength margin, and operating leverage complement the results of the economic evaluation of HRM projects and are secondary for decision making. These are indicators that are widely used in economic calculations, and the authors use a standard approach in their calculation formulas. The formulas for these indicators were given in earlier works by the authors.

The main economic criterion for making decisions on operational HRM projects is additional profit from sales. This indicator can be calculated when evaluating projects in special tables (an example in Table 4) or, which sometimes simplifies and speeds up the work, according to the special formula Dep max proposed in the article.

\section{Discussion: Personnel Management and Open Innovation}

\subsection{Organizational Project and Personnel Management}

Discussing the connection between personnel management and open innovation concept, the authors could explain the ideas contributing to previous research in both theoretical and methodological levels as well as the empirical level. From the theoretical point of view, the authors have made an attempt to consider a special approach to assessment of organizational HRM projects as a system for localizing projects using a simplified approach to calculating costs, income, and the level of operational risks. In terms of further improvement, the business process of economic assessment and decision-making on projects with the target focus "increasing the volume of sales and reducing the cost, operating costs" is currently being worked out in more detail.

As far as the methodological level is concerned, the economic focus of HR management projects is identified in the article and the assessment of it is determined to be based on two factors: determination of the commercial efficiency and the impact of the project on operational characteristics of the enterprise. The goal of this study consisted in clarifying some important issues regarding the increase of the level of digitalization of HRM processes (taking into account the definition of digital ecosystems [61], as well as the features of the personnel management digital model [62]), such as both developing clear criteria for assessing the effectiveness of such projects and determining the regulatory framework for costs and incomes from improving personnel management systems for enterprises of different industries and types of activities, sizes, and specializations.

Considering the empirical level, the authors could prove that the practical contribution of the article is to create a scientific basis for the development at various enterprises of their own methods of economic evaluation of HRM projects. The technique is actively used by 
various enterprises of St. Petersburg (Russia) in their activities, as well as by the Russian universities in the educational process. A serious approach to planning the development of enterprises always involves the development of several scenarios. For the economic study of such scenarios for the development of the personnel management system, the methodological materials outlined in the article are recommended.

The authors have found that the approach to the learning flows in the project-based organizations [63] could be considered as being in accordance with the findings in this research. The authors agree that an organizational context takes place in different fields. So, the approach to investigating any specific issue (e.g., a multilevel of learning flows approach [63]) could be considered from the organizational point of view at individual, team, and organizational levels. The work [64] proves that the organizational challenges are an underestimated area in projects. Thus, the authors could assume that investigating the organizational projects in personnel management is an important part of the research at theoretical, methodological, and empirical levels.

\subsection{Personnel Management in Projects for Open Innovation}

The findings considered as a fundamental theory for the authors' approach include Christensen's determinants of an open innovation model associated with the industrial dynamics of an industry segment undergoing a process of radical technological innovation [65] unraveling the Chesbrough's Open Innovation concept, which was initially studied from the company-level perspective (in contrast to the closed innovation old model). JinHyo Joseph Yun considered the open innovation engineering model, including both open-innovation engineering channels and determining ways of operating the channels through conceptual experiments [66]. The effects of the mechanism design (fundamental to the study of incentives and information [67]) could be expanded and implemented for developing new business model from open innovation and Schumpeterian new combinations [68,69], as well as an open innovation based business model design compass [70].

The implementation of innovative activities by companies is always associated with the implementation of innovative projects. Within the framework of the open innovation concept [71], any idea can be inside the company and turn into its project: a project with a result in the form of a finished product, and an organizational project with a result in the form of improving any processes. The consideration organizational HRM projects from the point of view of open innovation concept could be an interesting approach for further research.

\section{Conclusions}

Let us now summarize the key findings of the study.

1. The authors have developed special comparative tables that will allow the most correct analysis of the proposed calculations and facilitate the adoption of rational decisions in the implementation of projects.

2. The methodology proposed by the authors allows obtaining maximum values for costeffective projects; in addition, at the stage of the calculation program, unprofitable projects will be immediately cut off, which allows us to reduce the time for their analysis and use the resources for the implementation of the effective projects.

3. An important issue considered is the separation of organizational projects from investment projects for economic evaluation. Development for this group of projects involves a simplified one-stage methodology for economic assessment and a specific criterion-additional profit from sales. The proposed approach could be treated as a special concept for evaluating organizational PM projects: a system for localizing projects, as well as a simplified approach to calculating costs, revenues, and the level of operational risks.

The article proposes a system of economic calculations, including a preliminary assessment of the maximum acceptable costs for a specific enterprise, a business process for calculating costs and revenues for planned HRM projects, and a criterion for making 
decisions on the implementation of organizational projects in the form of additional profit from sales.

An important debatable issue is the separation of organizational projects from investment projects for economic evaluation. Development was completed for this group of projects of a simplified one-stage method of economic assessment and a specific criterion that is additional profit from sales.

The proposed methodology can be used in practical implementation of professional standards at the enterprise, in team building, and in successful interaction within them, aiming at the implementation of certain innovative tasks. Moreover, the methodology can be a certain guideline for employers as to what criteria are important for a particular function and what can be required from a specialist to achieve the assigned tasks. The technique has been tested and is effectively used in practice. The model has been tested in a number of enterprises from the considered sample.

It was found that the one-stage system of economic assessment of organizational HRM projects allows us to create an information base for reasonable decision-making on the implementation of projects and future digitalization of settlements. Furthermore, using a single economic criterion for organizational HRM projects in the form of additional profit from sales of the enterprise and control characteristics allows creating conditions for objective and reasonable decision-making on the implementation of projects.

The results obtained by the proposed approach can be valuable for innovative manufacturing enterprises, as well as for small and medium-sized enterprises in both the service sector (repair, food industry) and trade sector.

A limitation of the study is that the extent and structure of the Russian economy was excluded from consideration, as the authors preferred to focus on particular cases of HRM implementation. However, future studies can include this topic for a more thorough understanding of how the results obtained can be generalized for the Russian and European economy.

The following directions can be suggested for further research on the design and implementation of HR management projects at operating enterprises:

- a special methodology should be developed for economic assessment of organizational HRM projects, as opposed to investment,

- the model for finding the maximum acceptable amount of costs for the HRM project for specific enterprises should be tested to understand how it reduces the amount of necessary economic calculations in HR management and increases the validity of decisions.

Author Contributions: Conceptualization, A.B., O.K. and O.V.; methodology, N.V., M.C. and D.S.; writing-drafting, O.K. and N.O.; writing-inputs, all authors; writing—reviewing and editing, all authors. All authors have contributed substantially to the entire work reported. All authors have read and agreed to the published version of the manuscript.

Funding: This research work was supported by the Academic Excellence Project 5-100 proposed by Peter the Great St. Petersburg Polytechnic University.

Acknowledgments: The authors would like to thank the anonymous referees for their very useful suggestions.

Conflicts of Interest: The authors confirm that there is no conflict of interests to declare for this publication.

\section{References}

1. Dobrolyubova, E.; Alexandrov, O.; Yefremov, A. Is Russia Ready for Digital Transformation? Commun. Comput. Inf. Sci. 2017, 745, 431-444. [CrossRef]

2. Trusova, N. Government socio-economic policy under the digital economy in the foreign countries and Russia. Econ. Ann. 2019, 180, 88-96. [CrossRef]

3. Barmuta, K.A.; Akhmetshin, E.M.; Andryushchenko, I.Y.; Tagibova, A.A.; Meshkova, G.V.; Zekiy, A.O. Problems of business processes transformation in the context of building digital economy. Entrep. Sustain. Issues 2020, 8, 945-959. [CrossRef] 
4. Berman, S.J. Digital transformation: Opportunities to create new business models. Strateg. Leadersh. 2012, 40, 16-24. [CrossRef]

5. Romanovskaya, E.V.; Kuznetsov, V.P.; Andryashina, N.S.; Garina, E.P.; Garin, A.P. Development of the System of Operational and Production Planning in the Conditions of Complex Industrial Production. In Digital Economy: Complexity and Variety vs. Rationality; Springer: Cham, Switzerland, 2020; pp. 572-583.

6. Vardarlier, P. Digital Transformation of Human Resource Management: Digital Applications and Strategic Tools in HRM. In Contributions to Management Science; Springer Nature Switzerland AG: Cham, Switzerland, 2020; pp. $239-264$.

7. Donnelly, R.; Johns, J. Recontextualising remote working and its HRM in the digital economy: An integrated framework for theory and practice. Int. J. Hum. Resour. Manag. 2021, 32, 84-105. [CrossRef]

8. Munsamy, M.; Telukdarie, A. Digital HRM Model for Process Optimization by Adoption of Industry 4.0 Technologies. In Proceedings of the 2019 IEEE International Conference on Industrial Engineering and Engineering Management (IEEM), Macao, Macao, 15-18 December 2019; pp. 374-378.

9. Ziebell, R.-C.; Albors-Garrigos, J.; Schoeneberg, K.-P.; Marin, M.R.P. e-HRM in a Cloud Environment. Int. J. Hum. Cap. Inf. Technol. Prof. 2019, 10, 16-40. [CrossRef]

10. Jiang, K.; Takeuchi, R.; Jia, Y. Taking peers into account: Adoption and effects of high-investment human resource systems. J. Appl. Psychol. 2020. [CrossRef]

11. Independent Evaluation Division UNIDO Evaluation Manual. Available online: https://www.unido.org/sites / default/files / files/2018-04/EvaluationManuale-book.pdf (accessed on 3 March 2021).

12. Hayton, J.C. Promoting corporate entrepreneurship through human resource management practices: A review of empirical research. Hum. Resour. Manag. Rev. 2005, 15, 21-41. [CrossRef]

13. Kim, J.; Choi, S.O. The Intensity of Organizational Change and the Perception of Organizational Innovativeness; with Discussion on Open Innovation. J. Open Innov. Technol. Mark. Complex. 2020, 6, 66. [CrossRef]

14. Kaur, R.; Awasthi, A.; Grzybowska, K. Evaluation of Key Skills Supporting Industry 4.0-A Review of Literature and Practice. In Sustainable Logistics and Production in Industry 4.0. EcoProduction (Environmental Issues in Logistics and Manufacturing); Springer: Cham, Switzerland, 2020; pp. 19-29.

15. Van Laar, E.; van Deursen, A.J.A.M.; van Dijk, J.A.G.M.; de Haan, J. The relation between 21st-century skills and digital skills: A systematic literature review. Comput. Hum. Behav. 2017, 72, 577-588. [CrossRef]

16. Rodrigo, L.; Palacios, M. What antecedent attitudes motivate actors to commit to the ecosystem of digital social innovation? Technol. Forecast. Soc. Chang. 2021, 162, 120394. [CrossRef]

17. MacCrory, F.; Westerman, G.; Alhammadi, Y.; Brynjolfsson, E. Racing with and against the machine: Changes in occupational skill composition in an Era of rapid technological advance. In Proceedings of the 35th International Conference on Information Systems 'Building a Better World Through Information Systems, ICIS 2014, Auckland, New Zealand, 14-17 December 2014.

18. Hirzel, A.K. A systematic review on the role of human resources for process innovation. Int. J. Bus. Environ. 2017, 9, 279. [CrossRef]

19. Macke, J.; Genari, D. Systematic literature review on sustainable human resource management. J. Clean. Prod. 2019, 208, 806-815. [CrossRef]

20. Op de Beeck, S.; Wynen, J.; Hondeghem, A. Explaining Effective HRM Implementation: A Middle Versus First-Line Management Perspective. Public Pers. Manag. 2018, 47, 144-174. [CrossRef]

21. Bos-Nehles, A.; Renkema, M.; Janssen, M. HRM and innovative work behaviour: A systematic literature review. Pers. Rev. 2017, 46, 1228-1253. [CrossRef]

22. Lado, A.A.; Wilson, M.C. Human Resource Systems and Sustained Competitive Advantage: A Competency-Based Perspective. Acad. Manag. Rev. 1994, 19, 699-727. [CrossRef]

23. Kucharčíková, A.; Mičiak, M.; Hitka, M. Evaluating the Effectiveness of Investment in Human Capital in E-Business Enterprise in the Context of Sustainability. Sustainability 2018, 10, 3211. [CrossRef]

24. Albrecht, S.L.; Bakker, A.B.; Gruman, J.A.; Macey, W.H.; Saks, A.M. Employee engagement, human resource management practices and competitive advantage. J. Organ. Eff. People Perform. 2015, 2, 7-35. [CrossRef]

25. Victorova, N.G.; Valebnikova, N.V.; Valebnikova, O.A. Improvement of methods of budgeting for the industrial enterprises of the Russian Federation for the purpose of maintaining essential competitive advantages in Hi-tech sectors of economy. In Proceedings of the 33rd International Business Information Management Association IBIMA 2019 Education Excell. Innov. Manag. through Vis. 2020, Granada, Spain, 10-11 April 2019; pp. 1689-1700.

26. Valebnikova, O.A.; Valebnikova, N.V.; Kalinina, O.V. Intellectually-oriented consulting for financial function in the era of technology and digitalization. In Proceedings of the European Conference on Knowledge Management (ECKM), Lisbon, Portugal, 5-6 September 2019; Volume 2, pp. 1069-1078. [CrossRef]

27. Shaw, J.D.; Park, T.-Y.; Kim, E. A resource-based perspective on human capital losses, HRM investments, and organizational performance. Strateg. Manag. J. 2013, 34, 572-589. [CrossRef]

28. Lopez-Cabrales, A.; Valle-Cabrera, R. Sustainable HRM strategies and employment relationships as drivers of the triple bottom line. Hum. Resour. Manag. Rev. 2020, 30, 100689. [CrossRef]

29. Wang, Z.; Wang, N.; Cao, J.; Ye, X. The impact of intellectual capital-Knowledge management strategy fit on firm performance. Manag. Decis. 2016, 54, 1861-1885. [CrossRef] 
30. Lo, C.; Wang, C.; Chen, Y.-C. The Mediating Role of Intellectual Capital in Open Innovation in the Service Industries. Sustainability 2020, 12, 5220. [CrossRef]

31. Laursen, K.; Foss, N.J. Human Resource Management Practices and Innovation; Oxford University Press: Oxford, UK, 2014.

32. Wikhamn, W. Innovation, sustainable HRM and customer satisfaction. Int. J. Hosp. Manag. 2019, 76, 102-110. [CrossRef]

33. Sardi, A.; Sorano, E.; Garengo, P.; Ferraris, A. The role of HRM in the innovation of performance measurement and management systems: A multiple case study in SMEs. Empl. Relat. Int. J. 2020. [CrossRef]

34. Nijs, S.; Gallardo-Gallardo, E.; Dries, N.; Sels, L. A multidisciplinary review into the definition, operationalization, and measurement of talent. J. World Bus. 2014, 49, 180-191. [CrossRef]

35. Osranek, R.; Zink, K.J. Corporate Human Capital and Social Sustainability of Human Resources. In Sustainability and Human Resource Management; Ehnert, I., Harry, W., Zink, K., Eds.; Springer: Berlin/Heidelberg, Germary, 2014; pp. 105-126.

36. Písař, P. European SMEs' value management based on controlling, financial analysis and ratios-Empirical study. Investig. Manag. Financ. Innov. 2019, 16, 277-289. [CrossRef]

37. Koster, F.; Benda, L. Innovative human resource management: Measurement, determinants and outcomes. Int. J. Innov. Sci. 2020, 12, 287-302. [CrossRef]

38. Abdul-Halim, H.; Che-Ha, N.; Geare, A.; Ramayah, T. The pursuit of HR outsourcing in an emerging economy: The effects of HRM strategy on HR labour costs. Can. J. Adm. Sci. / Rev. Can. des Sci. l'Adm. 2016, 33, 153-168. [CrossRef]

39. Van der Laken, P.; Bakk, Z.; Giagkoulas, V.; van Leeuwen, L.; Bongenaar, E. Expanding the methodological toolbox of HRM researchers: The added value of latent bathtub models and optimal matching analysis. Hum. Resour. Manag. 2018, 57, 751-760. [CrossRef]

40. Monteiro, B.; Santos, V.; Reis, I.; Sampaio, M.C.; Sousa, B.; Martinho, F.; Sousa, M.J.; Au-Yong-oliveira, M. Employer branding applied to smes: A pioneering model proposal for attracting and retaining talent. Information 2020, 11, 574. [CrossRef]

41. Kargas, A.; Tsokos, A. Employer Branding Implementation and Human Resource Management in Greek Telecommunication Industry. Adm. Sci. 2020, 10, 17. [CrossRef]

42. Chen, S.H.; Lee, H.T. Performance evaluation model for project managers using managerial practices. Int. J. Proj. Manag. 2007, 25, 543-551. [CrossRef]

43. Keegan, A.; Huemann, M.; Turner, J.R. Beyond the line: Exploring the HRM responsibilities of line managers, project managers and the HRM department in four project-oriented companies in the Netherlands, Austria, the UK and the USA. Int. J. Hum. Resour. Manag. 2012, 23, 3085-3104. [CrossRef]

44. Pons, D. Project Management for New Product Development. Proj. Manag. J. 2008, 39, 82-97. [CrossRef]

45. Van De Voorde, K.; Veld, M.; Van Veldhoven, M. Connecting empowerment-focused HRM and labour productivity to work engagement: The mediating role of job demands and resources. Hum. Resour. Manag. J. 2016, 26, 192-210. [CrossRef]

46. Irum, A.; Yadav, R.S. Human resource information systems: A strategic contribution to HRM. Strateg. Dir. 2019, 35, 4-6. [CrossRef]

47. Miterev, M.; Mancini, M.; Turner, R. Towards a design for the project-based organization. Int. J. Proj. Manag. 2017, 35, 479-491. [CrossRef]

48. Gareis, R.; Huemann, M. Change management and projects. Int. J. Proj. Manag. 2008, 26, 771-772. [CrossRef]

49. Begum, H.; Bhuiyan, F.; Alam, A.S.A.F.; Awang, A.H.; Masud, M.M.; Akhtar, R. Cost reduction and productivity improvement through HRIS. Int. J. Innov. Sustain. Dev. 2020, 14, 185. [CrossRef]

50. Obeidat, S.M. The link between e-HRM use and HRM effectiveness: An empirical study. Pers. Rev. 2016, 45, 1281-1301. [CrossRef]

51. Cristiani, A.; Peiró, J.M. Calculative and collaborative HRM practices, turnover and performance. Int. J. Manpow. 2019, 40, 616-642. [CrossRef]

52. Chadwick, C.; Li, P. HR systems, HR departments, and perceived establishment labor productivity. Hum. Resour. Manag. 2018, 57, 1415-1428. [CrossRef]

53. Kabalina, V.; Zelenova, O.; Reshetnikova, K. Contemporary Human Resource Management Practices in Russia: Flexibility under Uncertainty. Int. Stud. Manag. Organ. 2019, 49, 422-440. [CrossRef]

54. Blom, R.; Kruyen, P.M.; Van der Heijden, B.I.J.M.; Van Thiel, S. One HRM Fits All? A Meta-Analysis of the Effects of HRM Practices in the Public, Semipublic, and Private Sector. Rev. Public Pers. Adm. 2020, 40, 3-35. [CrossRef]

55. Grimshaw, D. International organisations and the future of work: How new technologies and inequality shaped the narratives in 2019. J. Ind. Relat. 2020, 62, 477-507. [CrossRef]

56. Connelly, C.E.; Fieseler, C.; Černe, M.; Giessner, S.R.; Wong, S.I. Working in the digitized economy: HRM theory \& practice. Hum. Resour. Manag. Rev. 2020, 100762. [CrossRef]

57. Bril, A.; Kalinina, O.; Levina, A. Two-stage commercial evaluation of engineering systems production projects for high-rise buildings. E3S Web Conf. 2018, 33, 3004. [CrossRef]

58. Bril, A.; Kalinina, O.; Kankovskaya, A.; Vilken, V. Operational risk management in financing environmental activities and personnel management projects. E3S Web Conf. 2019, 110, 02018. [CrossRef]

59. Latukha, M.; Poór, J.; Mitskevich, E.; Linge, D. Human resource management practices transferring from foreign firms to Russia: The case of MNCs subsidiaries. J. Bus. Res. 2020, 108, 476-486. [CrossRef]

60. Njoku, E.; Ruël, H.; Rowlands, H.; Evans, L.; Murdoch, M. An Analysis of the Contribution of e-HRM to Sustaining Business Performance. In HRM 4.0 For Human-Centered Organizations; Emerald Publishing Limited: West Yorkshire, UK, 2019; pp. 21-39. 
61. Barykin, S.Y.; Kapustina, I.V.; Kirillova, T.V.; Yadykin, V.K.; Konnikov, Y.A. Economics of Digital Ecosystems. J. Open Innov. Technol. Mark. Complex 2020, 6, 16. [CrossRef]

62. Barykin, S.; Kalinina, O.; Aleksandrov, I.; Konnikov, E.; Yadikin, V.; Draganov, M. Personnel Management Digital Model Based on the Social Profiles' Analysis. J. Open Innov. Technol. Mark. Complex. 2020, 6, 20. [CrossRef]

63. Wiewiora, A.; Chang, A.; Smidt, M. Individual, project and organizational learning flows within a global project-based organization: Exploring what, how and who. Int. J. Proj. Manag. 2020, 38, 201-214. [CrossRef]

64. Andersen, B.; Aarseth, W.; Rolstadås, A. Managing organizational challenges in global projects. Int. J. Manag. Proj. Bus. 2014, 7, 103-132. [CrossRef]

65. Christensen, J.F.; Olesen, M.H.; Kjær, J.S. The industrial dynamics of Open Innovation-Evidence from the transformation of consumer electronics. Res. Policy 2005, 34, 1533-1549. [CrossRef]

66. Yun, J.J.; Kim, D.; Yan, M.R. Open innovation engineering-preliminary study on new entrance of technology to market. Electronics 2020, 9, 791. [CrossRef]

67. Vohra, R.V. Mechanism Design: A Linear Programming Approach; Cambridge University Press: Cambridge, MA, USA, 2011; ISBN 9781107004368.

68. Kage, J.H.; Roth, A.E. The Handbook of Experimental Economics. Am. Polit. Sci. Rev. 1996, 90, 632-633. [CrossRef]

69. Smith, V.L. Experimental Economics: Induced Value Theory. Pap. Exp. Econ. 2010, 100-105. [CrossRef]

70. Yun, J.J. (Ed.) Introduction BT_Business Model. Design Compass: Open Innovation Funnel to Schumpeterian New Combination Business Model. Developing Circle; Springer: Singapore, 2017; pp. 3-14. ISBN 978-981-10-4128-0.

71. Yun, J.J. Business Model. Design Compass. Open Innovation Funnel to Schumpeterian New Combination Business Model. Developing Circle; Springer Nature Singapore Pte Ltd.: Singapore, 2017; ISBN 978-981-10-4126-6. 